\title{
Facies, Depositional Environment and Sequence Stratigraphy of Dalan Formation in Persian Gulf (Qatar-South Fars Arch) Well SP-A Subsurface Section
}

\author{
Nasser Rezavand ${ }^{1 *}$, Davood Jahani' and Hossein Asilian² \\ 'Department of Geology, North Tehran Branch, Islamic Azad University, Tehran, Iran; \\ Rezavand_n@yahoo.com, Jahani_davood@yahoo.com \\ 2Department of Stratigraphy and Sedimentology, NIOC Exploration, Tehran, Iran; \\ Hosseinasilian@yahoo.com
}

\begin{abstract}
Objectives: Facies, depositional environment and sedimentary cycles of Dalan Formation in the South Pars gas field are the aspects that this paper is focused on. Methods/Statistical Analysis: Three hundred and seventy-eight thin-sections prepared from cutting and cores were evaluated by using petrographic microscope. Corel Draw X6, Autodesk Map, Corel Photo-Paint, Autodesk Map, DN2 Microscopy Image Processing System, Geocalc and Auto Cad 2014 employed for this research. Findings: Twenty-four major facies in five facies associations were identified comprising Tidal flat (A), Lagoon (B), Shoal (C), Open marine (D) and Mid ramp (E). The Dalan Formation was deposited in inner to mid parts of a homoclinal ramp. The sequence stratigraphy studies revealed the seven main third- order sedimentary cycles in the well SP-A. The shoal ooid grainstone facies with intergranular, moldicand fracture porosity comprise the main reservoir facies of the Dalan Formation. Dissolution, dolomitization, anhydritization, compaction and cementation are the main diagenetic processes in this formation which played an important role in the quality of the reservoir. Applications/Improvements: The results obtained from this paper, can be used to construct a major depositional framework in the Qatar-South Fars Arch for later exploration purposes.
\end{abstract}

Keywords: Dalan Formation, Depositional Sequence, Homoclinal Ramp

\section{Introduction}

The Dalan Formation, in the Persian Gulf, contains some of the important gas reserves such as North field and South Pars 1,2 . The Dalan anticline is located 110 kilometers S-SW of Shiraz city. The thickest section of the Dalan is in the northern Persian Gulf This formation is situated between the Faraghan and Kangan formations. The facies, sequence stratigraphy and sedimentary environment of Dalan Formation are the aspects that this paper is focused on. The thickness of the Dalan in well SP-A is about $756 \mathrm{~m}$ and is consists of clean limestone and dolomite with some intervals including oolites and peloids. The basal part is bioclastic containing open marine echinoderms, bryozoans, gastropods and brachiopods. Minor amount of quartz are found near the boundary with the Faraghan Formation. The Dalan Formation has been subdivided byf into three members comprising the Lower Dalan, Nar evaporite and the Upper Dalan Members. The QatarSouth Fars Arch separates the Persian Gulf basin into two areas characterized by significant Proterozoic Hormuz Salt diaprisim . The geographical coordinates of the South Pars gas field and Well SP-A are $51^{\circ} 45^{\prime} \mathrm{E}$ to $52^{\circ} 24^{\prime} \mathrm{E}$; $26^{\circ} 30^{\prime}$ to $27^{\circ} 3^{\prime} \mathrm{N}$ and52 $2^{\prime} 29.1^{\prime \prime} \mathrm{E} ; 26^{\circ} 41^{\prime} 56.62^{\prime \prime} \mathrm{N}$ subsequently (Figure 1). 


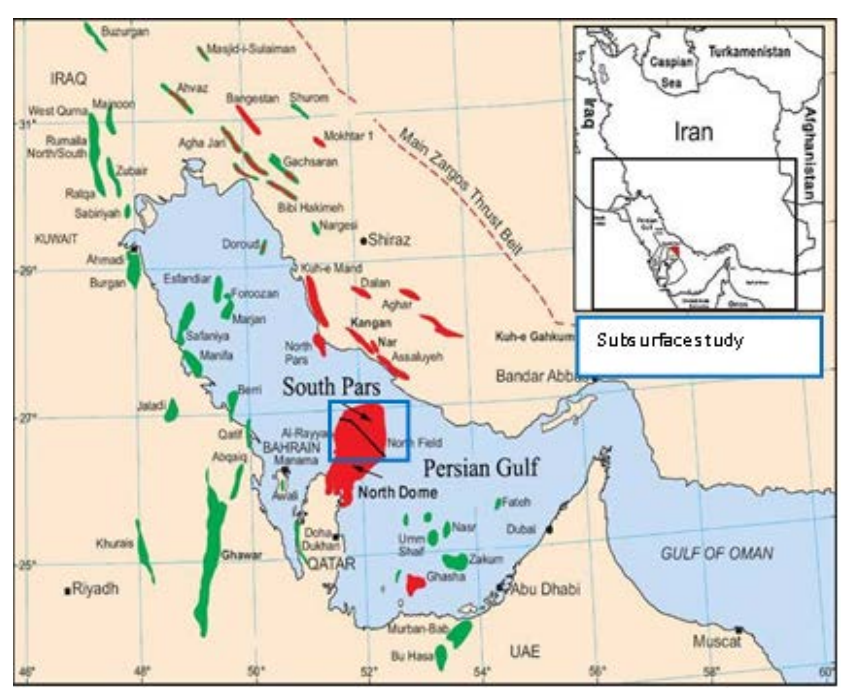

Figure 1. Location map of study area and regions discussed in the text.

Three hundred and seventy-eight thin-sections prepared from cuttings and cores were examined to identify microfacies types incarbonate rocks based on textural classifications of and diagnostic microfacies criteria off. Facies analysis and sequence stratigraphy concepts accomplished based onfer.

\section{Facies Classification}

\subsection{Facies Association A (Tidal Flat Facies)}

\subsubsection{Facies A1 (Massive to Layered Anhydrite)}

This facies contains more than 80 percent anhydrite including nodular, massive to finely laminated, bladed, sparse fine-grained crystals, needle type, fan type and equivalent to mosaic forms (Figure 2, A-F). The maximum thickness of anhydrite beds is about $25 \mathrm{~m}$. Although we can see this facies in Lower and Upper Dalan Members but however it is mostly developed through the Nar Member as supratidal sabkha-type deposits ${ }^{30-32}$ and also shallow coastal salinas?. The ghost of the original carbonate textures is commonly found through the samples. The western part of Persian Gulf is a modern analogue for this facies ${ }^{3-3}$.

\subsubsection{Facies A2 (Sandy Dolomudstone)}

At the base of Lower Dalan Member the quartz grains with wavy extinction are found in micritic matrix. The quartz grains are angular and the syntaxial overgrowth cement is absent which are indicative of first sedimentary cycle. The intercrystalline porosity is well developed by vast dolomitization(Figure 3). This facies has developed on a supratidal setting during transgression of Neo-Tethys?
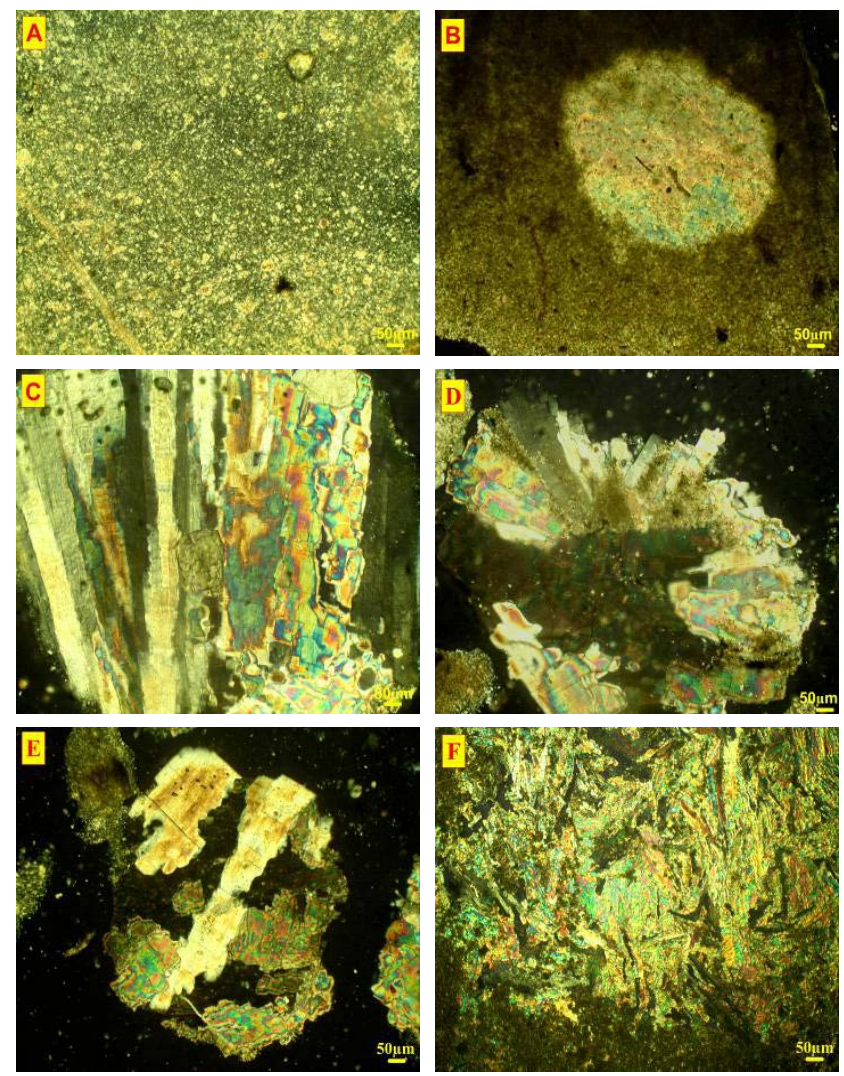

Figure 2. Facies A1 (Massive to layered anhydrite), A) Sparse fine- grained crystals, B) Anhydrite nodules "N", C) Bladed to columnar fabric, D) Fan type fabric, E) Equivalent to mosaic fabric and F) Fibrous to needle anhydrite (XPL).

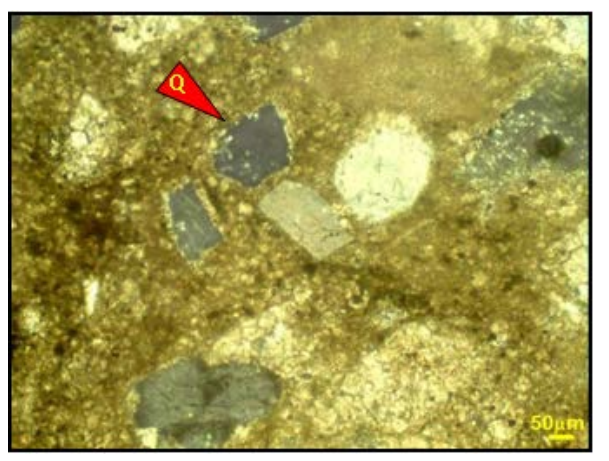

Figure 3. Facies A2 (Sandy dolomudstone), the quartz grains "Q" are sparse in micritic matrix (XPL).

\subsubsection{Facies A3 (Stromatolite Boundstone)}

This facies is characterized by striped or wavy laminations. The sparse anhydrite nodules are seen in the bright 
laminations. Traces of micro-faults and oil stains are also found(Figure 4, A-D). Presence of anhydrite and the lack of appropriate primary porosity have affected the reservoir quality. The modern stromatolites are found mainly in fresh waters, marginal seas and shallow subtidal environments, but ancient stromatolites are also found in deep subtidal and deep water environments/. On the base of the studies carried out in the Persian Gulf, the stromatolites developed in the upper parts of intertidal environments in arid climaten.

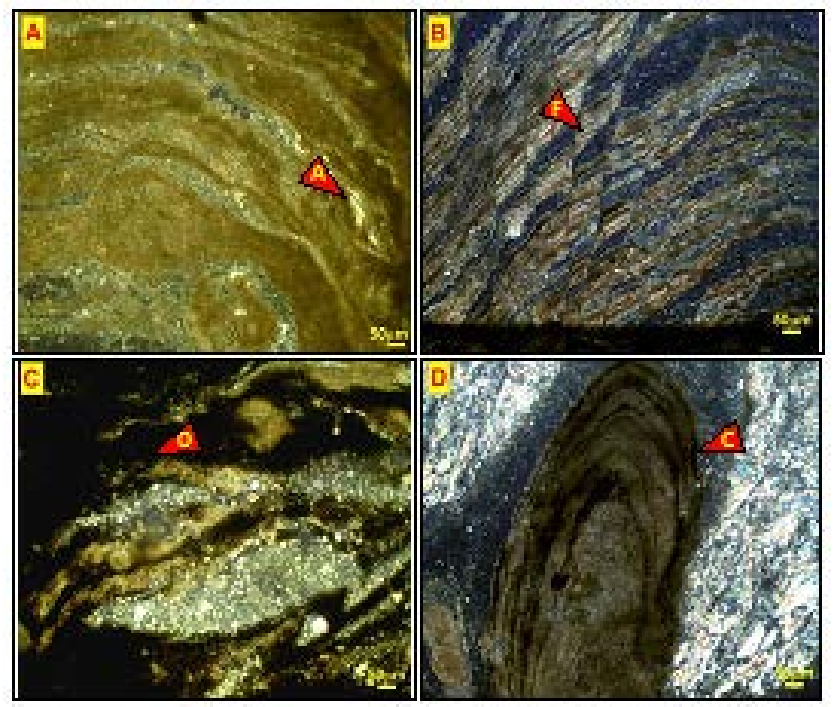

Figure 4. Facies A3 (Stromatolite boundstone), A) Wavy laminations with anhydrite nodules "A", B) Trace of microfaults " F", C) Trace of oil stain " $O$ " and D) Columnar stromatolite with dark and bright lamination associated with evaporites (XPL).

\subsubsection{Facies A4(NonBurrowed Mudstone)}

This facies consists of nonfossiliferous mudstone associated with fine-grain dolomicrite and evaporites. Bioturbation is rare but clay minerals and oil stain are found (Figure 5, A-B). Burrowers and browsers are seldom seen in arid climates because of evaporite formation and high salinity. Absence of subaerial exposure features indicates deposition in a subtidal lagoon or in an intertidal pond setting ${ }^{12}$.

\subsubsection{Facies A5 (Dolomitic Mudstone with Evaporite Casts)}

This facies contains fine-crystalline dolomites including Dolomicrosparite (Smaller than $62 \mu \mathrm{m}$ ) and Dolosparite (Greater than $62 \mu \mathrm{m}$ ) types. Evaporite casts with needle, fan type and equivalent fabrics are also found.
Changes between dolomite types, is usually associated with occurrence of pseudo-ooids which is indicative of intertidal environments (Figure 6, A-D). Lack of fossils, fine-grained dolomites and sparse anhydrite crystalsare evidence of intertidal, supratidaland other hypersaline environments f. Evaporitic dolomudstone can be formed in upper parts of intertidal settings 1 ?

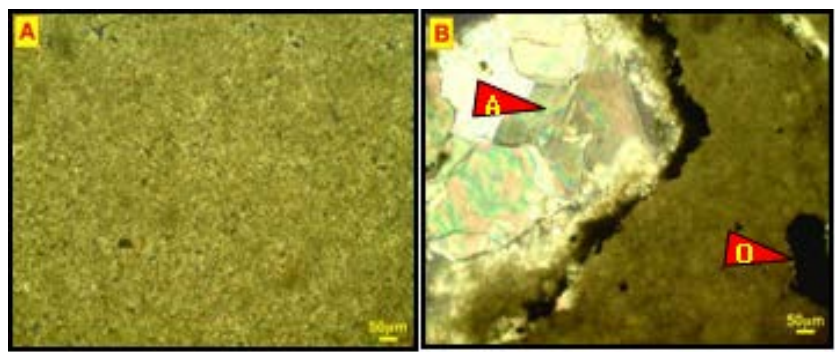

Figure 5. Facies A4 (Non Burrowed Mudstone), A) Microcrystalline homogeneous mudstone without bioturbation, B) Mudstone associated with anhydrite "A" and oil stain "O" (Core, XPL).

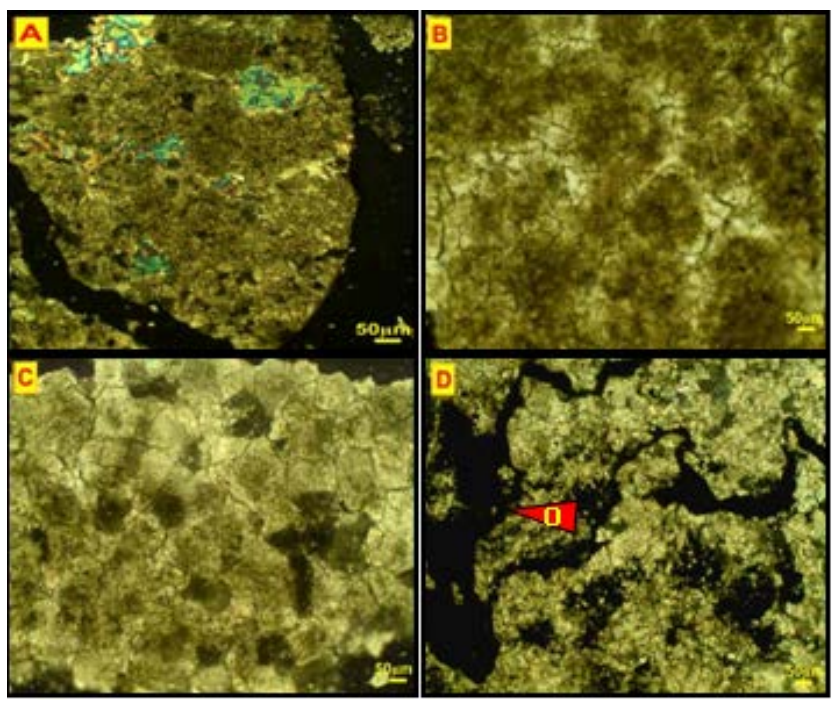

Figure 6. Facies A5 (Dolomitic mudstone with evaporite casts), A) Dolomicrosparite with anhydrite casts, B) Pseudo-ooids, C) Dolosparite (Crystals $>62 \mu \mathrm{m}$ ), and D) Dolomicrosparite associated with oil stain "O" (XPL).

\subsubsection{Facies A6 (Peloid Intraclast Packstone) Grainstone)}

This facies comprises intraclasts $(350 \mu \mathrm{m})$ and peloids $(100-150 \mu \mathrm{m})$. The facies includes micritic cement as well as spary cement, but anhydrite cement is also seen in some samples (Figure 7, A-B). The intraclasts are commonly found in shallow marine environments, but they are 
also transported to deep waters. Intraclast grainstones are often formed by storm wave erosion and sediment reworking in shallow marine settings ${ }^{12}$. The generation of intraclasts are common in the supratidal and intertidal environments, but also found in subtidal environments? Facies A6 is supposed to be developed in a tidal channel setting.

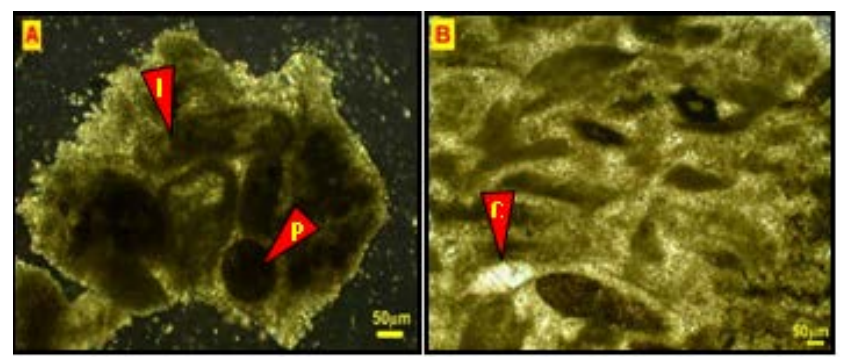

Figure 7. Facies A6 (Peloid intraclast packstone/ grainstone), A) Intraclasts "I" are found with peloids "P" and B) Anhydrite cement " $C$ " is found in some samples.

\subsection{Facies Association B (Lagoon Facies)}

\subsubsection{Facies B1 (Ooid Packstone/Grainstone with Micritic Ooids)}

This facies comprises ooids sized of $100-300 \mu \mathrm{m}$ with few lagoonal foraminifera. Superfecial ooids with one lamina and micritic nuclei are common which have medium sorting. The fragments of lagoonal foraminifera are found in some samples. The diagenetic processes are compaction, dissolution and cementation. The grain contacts are mostly tangential. Intergranular and moldic porosities are the common porosity generating a good porosity in combination with each other (Figure 8). The generation of ooids is common in sand shoals and shoreface f but micritic ooids with one lamina develop in brakish protected lagoons so, considering ooid type and adjacency with tidal flat facies, this facies is supposed to be developed in protected lagoons.

\subsubsection{Facies B2 (Peloid Packstone/Grainstone)}

Fine-grained peloids with good roundness and medium sorting are abundant. Benthic foraminifera are rarely found. (Figure 9, A-B). Considering the angular peloids they are ascribed to rounded micritic intraclasts
Dolomitization and anhydrite cement are common. With respect to the shape and size of peloids of subaerial exposure fabrics and rare skeletal grains which are indicative of high salinity settings with limited circulation 3 , this facies is developed in protected lagoon environment?

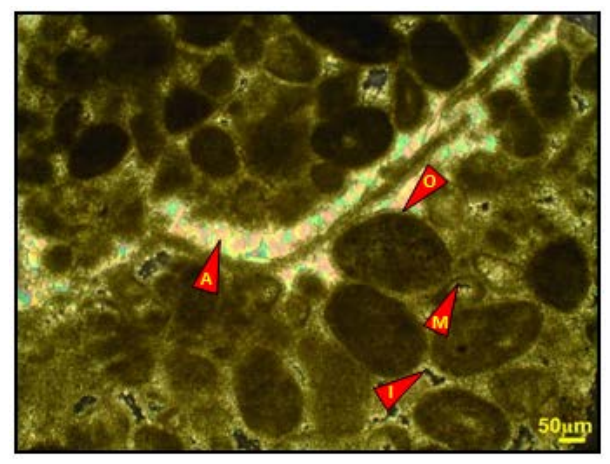

Figure 8. Facies B1 (Ooid packstone/ grainstone with micritic ooids), Superfecial ooids "O" with good compaction, Moldic " $M$ " and intergranular "I" porosity in addition with anhydrite cement (XPL).

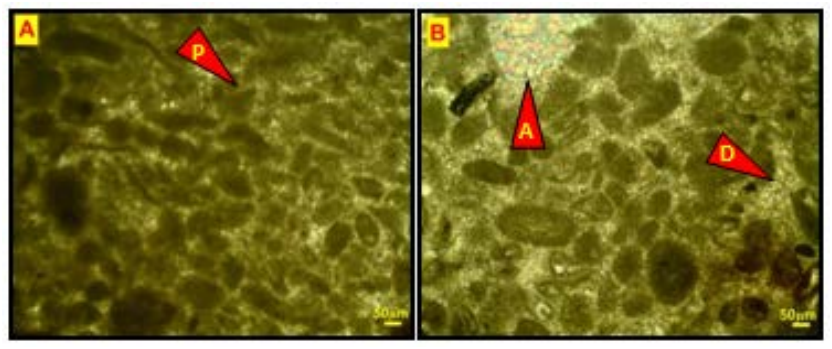

Figure 9. Facies B2 (Peloid packstone/ grainstone), A) Consideration the angular peloids "P", they are attributed to rounded micritic intraclasts, B) Dolomitization "D" and void filling anhydrite cement "A" are the most important diagenetic processes (XPL).

\subsubsection{FaciesB3 (Peloid Wackestone/Packstone with Calcispheres)}

This facies consists mainly of peloids and calcispheres. Spherical calcispheres are well preserved with micritic rim recognizable both outer and inner walls. This facies is found in Lower Dalan Member (Figure 10).Calcispheres are interpreted as algal cysts] Paleozoic calcispheres occur in shallow-marine platform and ramp carbonates. Calcispheres are also considered as a source of lime mud and peloids? 


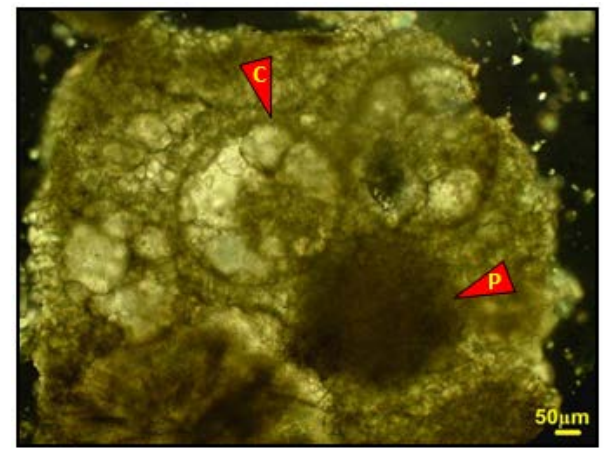

Figure 10. Facies B3 (Peloid wackestone/ packstone with calcispheres), Calcispheres " $\mathrm{C}$ " with recognizable both inner and outer walls in addition with peloids "P" are seen in dolomitic micrite matrix (XPL).

\subsubsection{Facies B4 (Bioclast Wackestone/Packstone with Algal and Benthic Foraminifera)}

This facies comprises dasyclads such as Mizzia and benthic foraminifera accompanied by gastropods, peloids, ooids and intraclasts. The matrix contains micrite and spary cement. Dissolution, dolomitization and cementation are important diagenetic process. Moldic and intergranular porosity is well developed but, however, is plugged by anhydrite cement in some samples (Figure 11, A-D). With respect to the assemblage of dasyclads and large foraminifera this facies characterize the shallow photic and dysphotic parts of a carbonate rampt

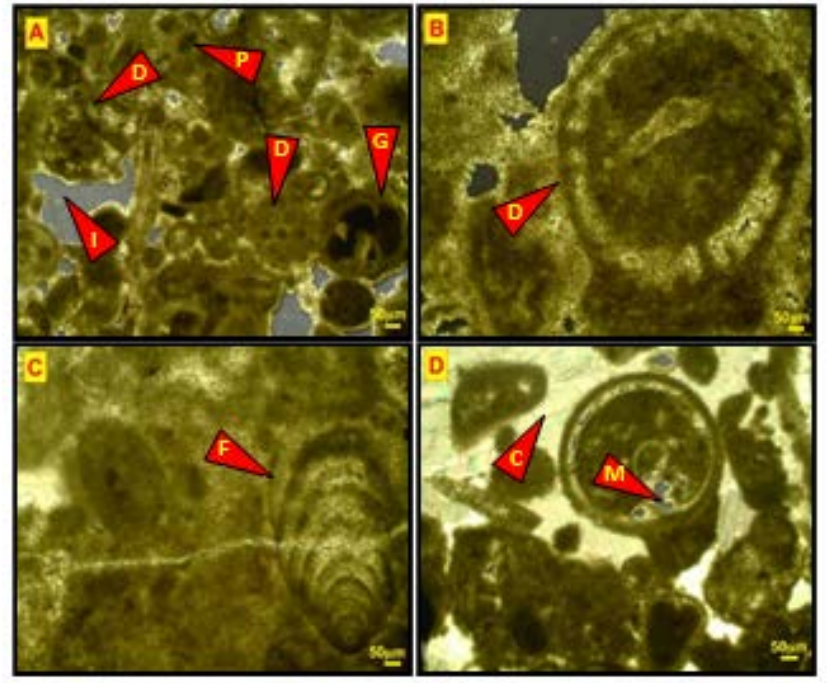

Figure 11. Facies B4 (Bioclast wackestone/ packstone with algal and benthic foraminifera), A) Dasyclad green algae "D" associated with gastropods "G" and peloids "P" in addition of well developed intergranular porosity "I", B) Dasyclad green algal " $D$ ", B) Sparse benthic foraminifera "F" in micritic matrix, D) Pervasive anhydrite cement " $C$ " and moldic porosity "M" (Core, XPL).

\subsubsection{Facies B5 (Peloid Packstone with Gymnocodiacean)}

Peloids associated with gymnocodiacean algae are the most important constituents of this facies. Dolomitization and cementation are common diagenetic features (Figure 12, A-B).Considering the peloid types and presence of gymnocodiacean algae, this facies is attributed to low energy lagoonal environments

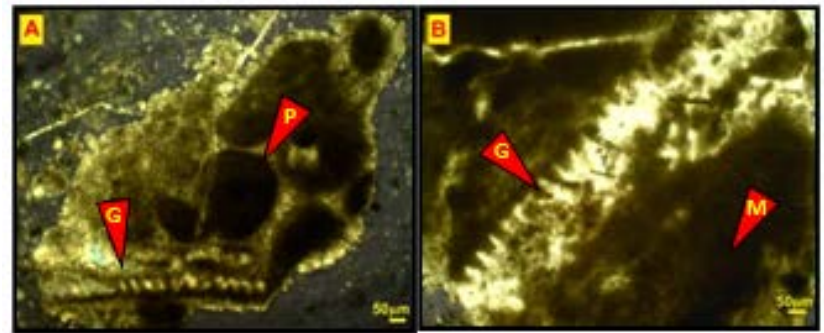

Figure 12. Facies B5 (Peloid Packstone with Gymnocodiacean), A) Peloids "P" are found associated with Gymnocodiacean "G", B) The lime Micrite " $M$ " is generated by disintegration of calcareous green algae in Helmida model.

\subsubsection{Facies B6 (Fusulinid Wackestone)}

This facies comprises fusulinds accompanied by peloids, benthic foraminiferaand intraclasts. The matrix is micritic (Figure 13). Although fusulinids are found through the Dalan Formation, but they are common at the top of Lower Dalan Member. Adjacency with lagoonal facies, low diversity of fusulinids and presence of benthic foraminifera are indicative of lagoonal environments.

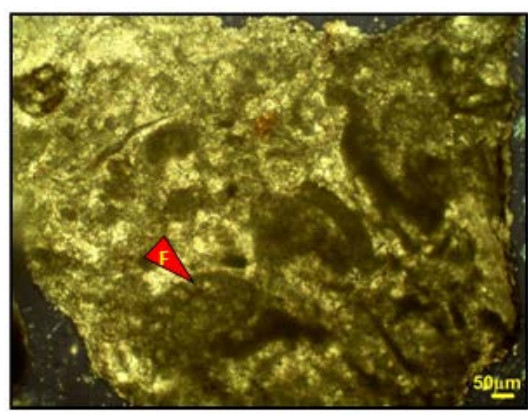

Figure 13. Facies B6 (Fusulinid wackestone), Fusulinids "F" are seen in addition with peloids and intraclasts (XPL).

\subsubsection{Facies B7 (Mudstone with Lagoonal Foraminifera)}

The matrix is micritic containing some lagoonal forams such as "Geinitzina sp". Burrowing and bioturbation 
are rare (Figure 14). Low diversity and micritic matrix denotes quiet-water and low energy settings:

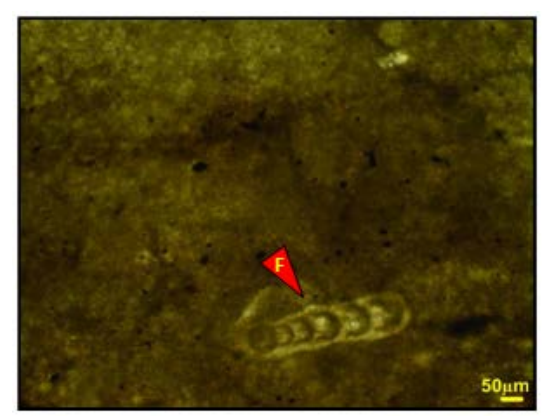

Figure 14. Facies B7 (Mudstone with lagoonal foraminifera), Lagoonal foraminifera "F" are sparse in micritic matrix (XPL).

\subsubsection{Facies B8 (Bioclast Packstone with Gastropod)}

Gastropods are the main constituents of facies B8 but, however, echinoderm, bryozoans, dasyclads, brachiopods peloids, bivalve and foraminiferaare also seen (Figure 15, A-C). Bryozoans and brachiopods, in Dalan Formation, are mostly found in shoal and Mid-ramp settings.]. Combination of gastropods, bryozoans and brachiopods living settings/ and considering the presence of dasyclads, this facies is attributed to back barrier lagoons.
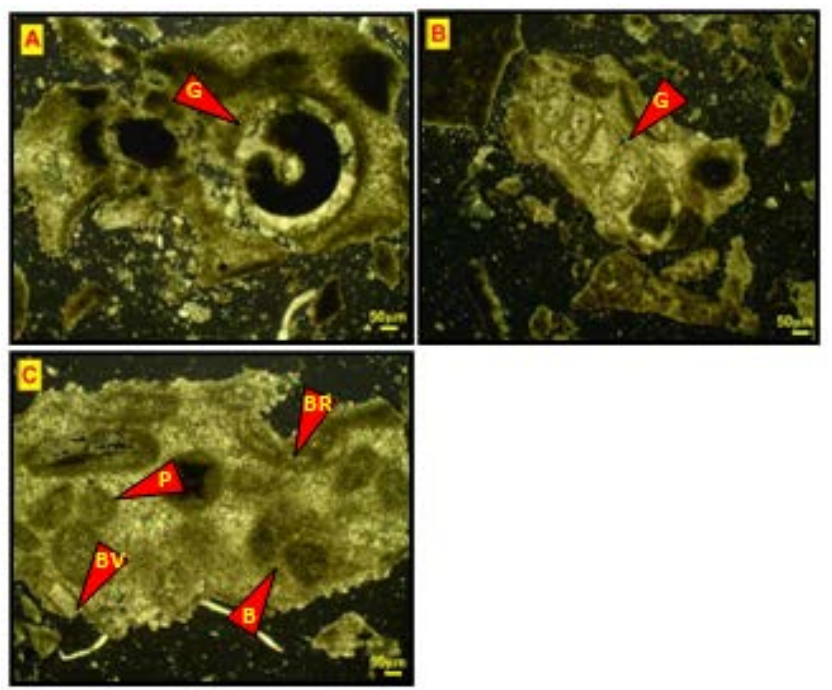

Figure 15. Facies B8 (Bioclast packstone with gastropod), A) Gastropods " $G$ " in tangential section, B) Gastropod " $G$ " in axial section, C) Bryozoan "B", brachiopod "BR" andbivalve "BV" fragments associated with peloids "P" (XPL).

\subsection{Facies Association C (Shoal Facies)}

\subsubsection{Facies C1 (Dasyclad Packstone/Grainstone)}

Facies C1 includes Mizzia green algae and superfecial ooids. Compaction, dissolution, cementation and dolomitization are important diagenetic processes. Fabric selective and mimic dolomitization is well developed and pervasive anhydrite cement is found in some samples. Intergranular and moldic porosity are common (Figure 16, A-B). High diversity of green algae indicates normal open marine with good circulation, whereas low diversity and abundant of one type is indicative of restricted environmentsf. Mizzia Velebitana is the most important green algae found in the well SP-A.

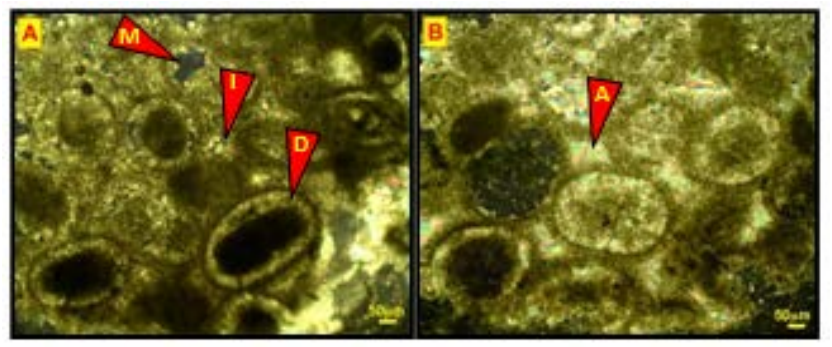

Figure 16. Facies C1 (Dasyclad packstone/ grainstone), A) Dasyclad "D" green algae associated with moldic " $M$ " and intergranular "I" porosity that generate good porosity in combination with each other, B) Pervasive anhydrite cement " $\mathrm{A}$ " is developed in some samples.

\subsubsection{Facies C2 (Bioclast Ooid Packstone/ Grainstone)}

Ooids comprising $30-40 \%$ of the allochems are mostly superfecial and broken in part.In addition to ooids, peloids as well as few amounts of foraminifera, dasyclads and intraclasts are found. Dissolution, cementation, dolomitization and compaction are common. Dripstone cement, resulting of dissolution, is found in some samples (Figure 17, A-B). As water energy increases, a number of peloids are carried from lagoon environments to high energy sand shoals. High amounts of ooids, lack of micrite and presence of low energy facies denote leewardshoal environments $\mathrm{A}^{2}$. 


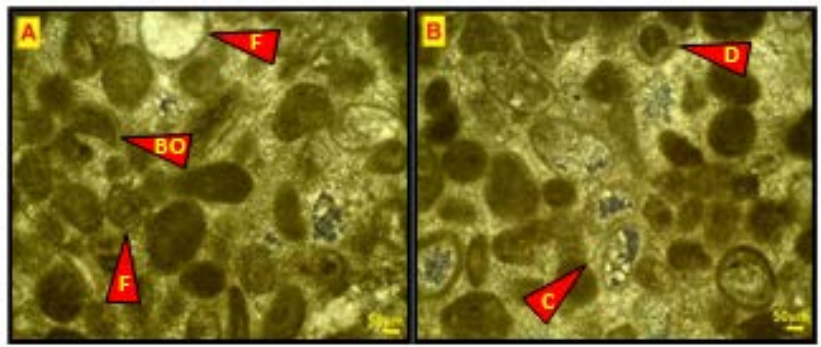

Figure 17. Facies C2 (Bioclast ooid packstone/ grainstone), A) Broken ooids "BO" and benthic foraminifera " $\mathrm{F}$ " associated with peloids are seen, B) Dasyclads “ $D$ ” are found with ooids and peloids. Dripstone cement " $\mathrm{C}$ " resulting of dissolution is found in some sample (XPL).

\subsubsection{Facies C3 (Dolomitized Ooid Grainstone)}

$200-300 \mu \mathrm{m}$ sized ooidscomprise $80 \%$ of this facies. They are mimically replaced and still show concentric microstructure (Figure 18, A-D). There is a good reservoir potential due to the vast dissolution and dolomitization. With attention to the ooids size, shape, number of laminae and the thickness of their cortex this facies is attributed to shoal settings 36,37 . Bahamas and Persian Gulf are the modern analogue for this facies .

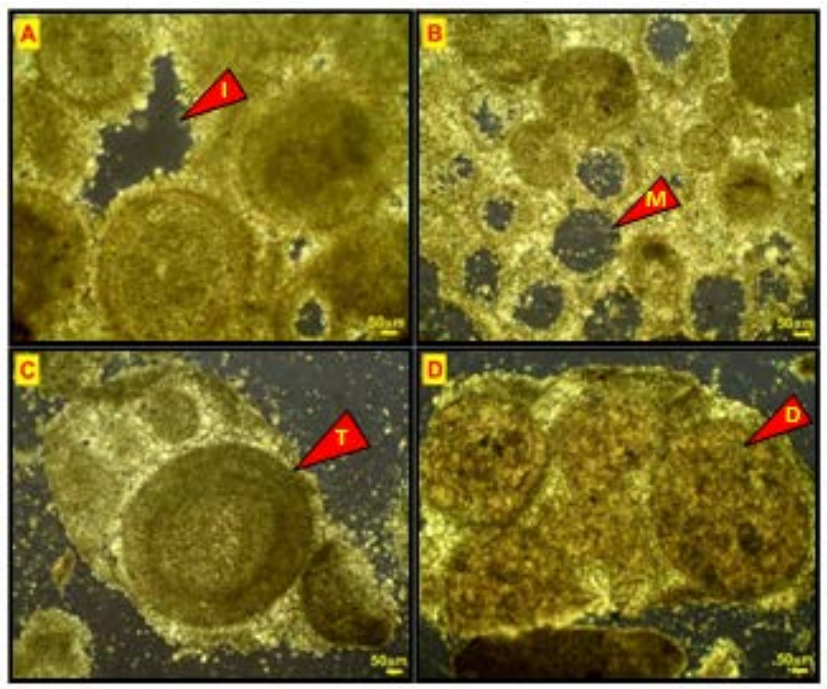

Figure 18. Facies C3 (Dolomitized ooid grainstone), Spherical ooids are seen with good intergranular "I" porosity, B) Moldic porosity "M" known as oomoldic porosity is well developed in some samples, C) Ooids still exhibit concentric or tangential “ $T$ ” microstructure, D) Mimic dolomitization " $\mathrm{D}$ " is common.

\subsubsection{Facies C4 (Intraclast Grainstone)}

Intraclast grainstone facies contains high amounts of rounded and well sorted intraclasts $(300-600 \mu \mathrm{m})$ associated with echinoderms, bryozoans and foraminifera which can be seen inside the intraclasts. The marine and burial cements are developed. This facies is common in Upper Dalan Member (Figure 19, A-B). Intraclasts can be generated in both high and low energy settings indicating the agitated water and transportation. Considering rounded intraclasts with conglomerate pattern and lack of micrite, this facies is developed in high energy shoal setting above the fair-weather wave base (FWWB). Isopachous rimmed cement conforms developing of this facies in high energy phreatic marine environments ${ }^{3}$

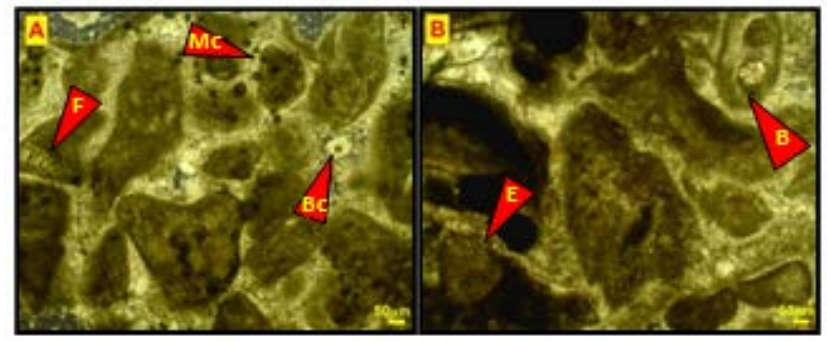

Figure 19. Facies C4 (Intraclast grainstone), A) Benthic foraminifera " $F$ " is seen inside the rounded intraclasts. Isopachous marine cement " $\mathrm{Mc}$ " and burial cement " $\mathrm{Bc}$ " are developed in this facies, B) A few amount of bryozoans "B" and echinoderms " $E$ " are found in this facies (XPL).

\subsubsection{Facies C5 (Coarse-Grain Intraclast Bioclast Grainstone)}

Coarse-grain echinoderms, bryozoans and intraclasts are common constituents of facies C5. In addition of marine and burial cement, the syntaxial echinoderm cement is also seen (Figure 20, A-D). Bryozoans and echinoderms which form "Bryonoderm" grains denote euphotic water depth (zone 2) where the echinoderms are frequently reworked 4 .

\subsubsection{Facies C6 (Bioclast Intraclast Packstone/ Grainstone with Oriented Grains)}

Facies C6 contains high amounts of intraclasts and echinoderms accompanied by foraminifera, spines, dasyclads and peloids. This facies is characterized by orientation of skeletal and non-skeletal grains (Figure 21). Inlet channels that trend nearly perpendicular to the length of the shoals import the sea water to lagoon settings. The salinity of the waters through the inlet channels changes, due to mixing of seawater and lagoonal water. A combination of different founa is found in the channel and the amount of marine founa decreases towards 
the lagoonal settings. Considering the combination of dasyclads with echinoderm and also intraclast with lagoonal foraminifera which are discordance according to ecology and water energy levels and orientation of skeletal and non-skeletal grains, this facies is generated in inlet channels?.

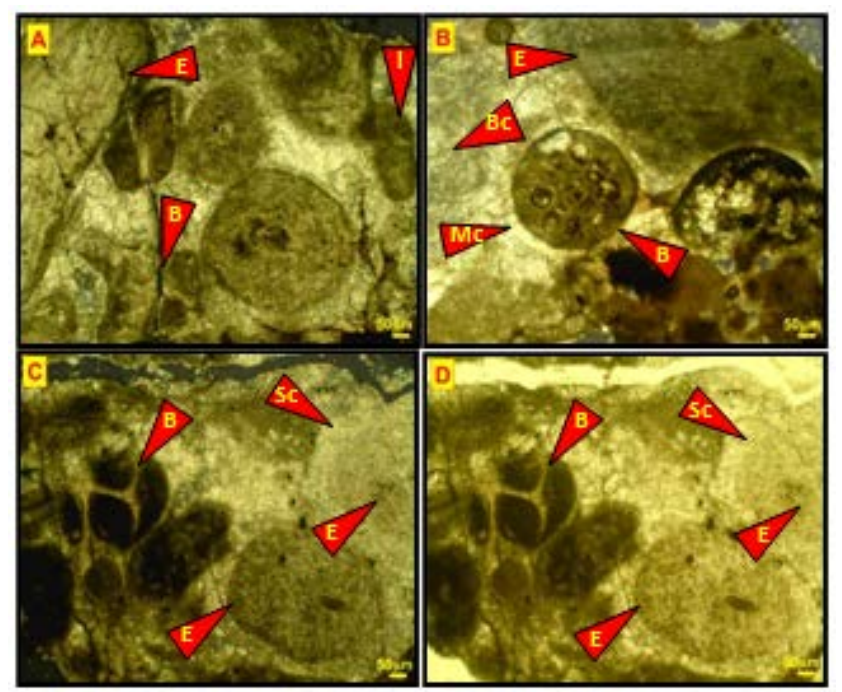

Figure 20. Facies C5 (Coarse grain intraclast bioclast grainstone), A) Coarse-grain echinoderms "E" and bryozoans "B" associated with intraclasts "I", B) Isopachous rimmed cement "Mc" and burial cement "Bc" are well developed, C \& D) Syntaxial echinoderm cement "Sc" is seen around echinoderms (A-C, XPL and D, PL).

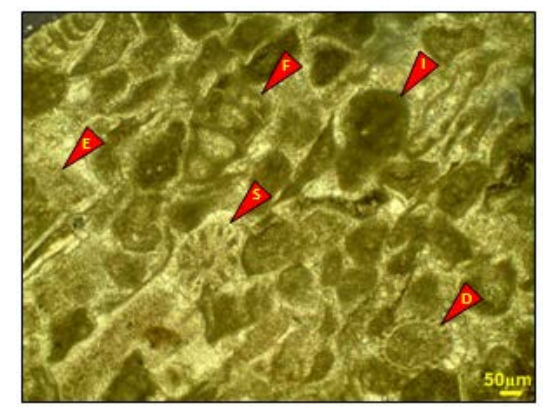

Figure 21. Facies C6 (Bioclast intraclast packstone/ grainstone with oriented grains), Echinoderms "E", dasyclads " D", intraclasts "I", foraminifera "F" and echinoderm spines "S" are found in combination of each other. Grains orientation and discordant ecology and water energy levels are important characteristic of this facies.

\subsection{Facies Association D (Open Marine Facies)}

\subsubsection{Facies D1 (Bioclast Wackestone/Packstone)}

Whole skeletal grains such as bryozoans, echinoderms and fusulinids are the important constituents of this facies. The matrix is micrite accompanied by spary cement. (Figure 22, A-C). Rare intraclasts, lack of green algae and also presence of whole echinoderms and bryozoans denote low energy open-marine settings
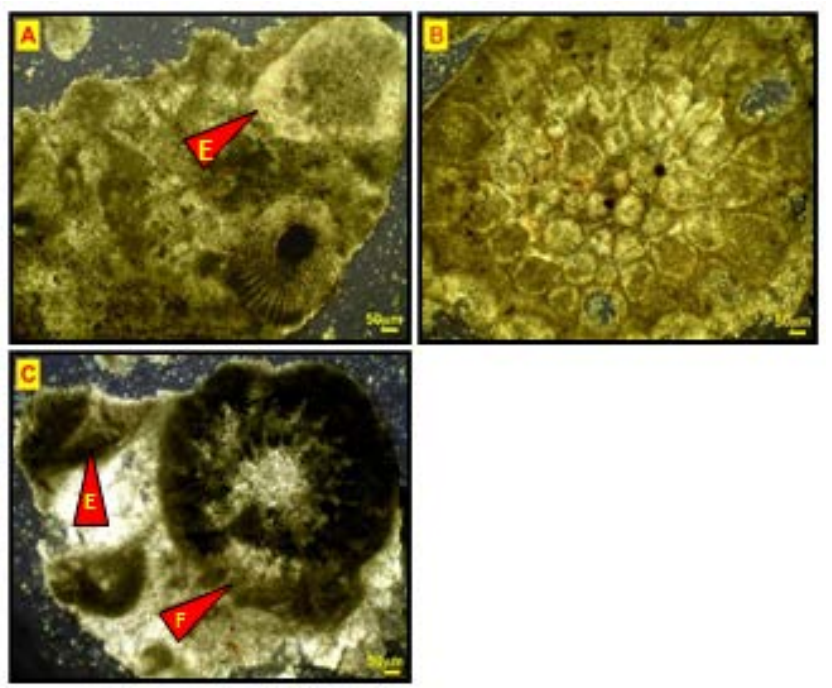

Figure 22. Facies D1 (Bioclast wackestone/ packstone), A) Echinoderms " $E$ " are sparse in a micritic matrix, B) Whole bryozoans are common, C) echinoderm " $\mathrm{E}$ " and fusulinid "F"associated with well developed spary cement (XPL).

\subsubsection{Facies D2 (Bioclast Mudstone)}

This facies contains low percentage of echinoderms and small foraminifera such as Hemigordius sp. and Longella sp. which are spars in micritic matrix (Figure 23, A-D). Plentiful micrite, infrequent skeletal grains, Lack of evaporites and intraclasts indicate the low energy openmarine environments 5 . 


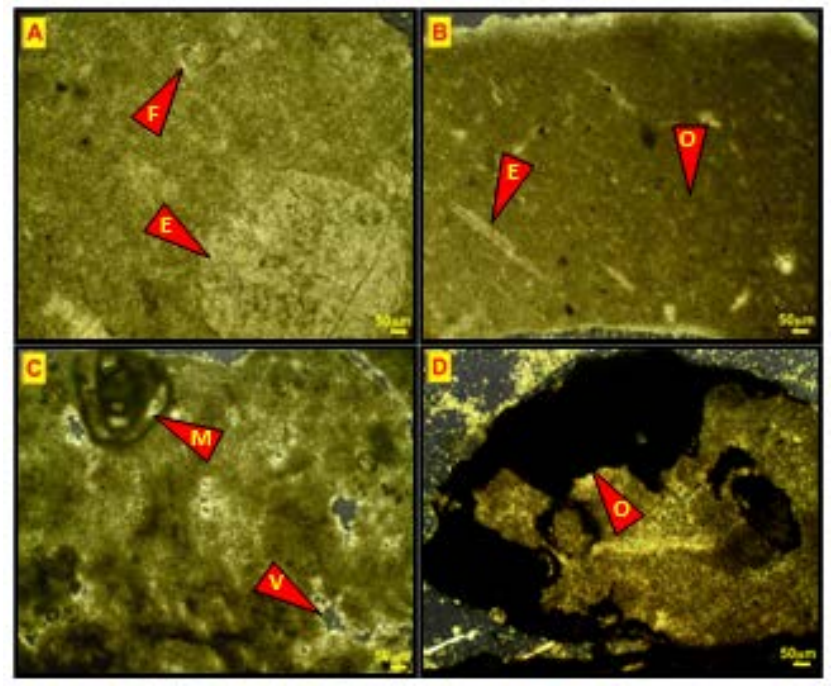

Figure 23. Facies D2 (Bioclast mudstone), A) Echinoderms "E" and small foraminifera " $F$ " are sparse in micritic matrix, B) Echinoderms "E" are seen with ostracods "O", C) Miliolid foraminifera " $\mathrm{M}$ " which is recognized only in this facies. Vuggy porosity "V" is also developed, D) Oil stain "O" is found in some samples (XPL).

\subsection{Facies Association E (Mid-Ramp Facies)}

\subsubsection{Facies E1 (Packstone with Ramp-Derived Intraclasts)}

This facies includes high percentage of $300 \mu \mathrm{m}-1.2 \mathrm{~mm}$ sized Intraclasts. In addition of intraclasts, $100-300 \mu \mathrm{m}$ sized peloids are found in this facies. The intraclasts are well rounded, but poorly sorted. This facies is developed only in Upper Dalan Member adjacent of open marine facies (Figure 24). Intraclast grainstones are often interpreted as deposits formed by storm wave erosion and reworking of various sediment types occurring in shallow-marine environments. The influence of storm wave erosion and subsequent erosion is more probable in the formation of these intraclasts than fair-weather processes, because of the extensive sea-floor cementation caused by microbialites carbonates. A specific type of lithoclasts is hardground intraclast found in deep shelf or basinal settings, sometimes called 'subsolution clasts'. These grains are $\mathrm{mm}$ to $\mathrm{cm}$ sized irregularly-shaped, predominantly micritic clasts]. This facies is developed in mid-ramp settings.

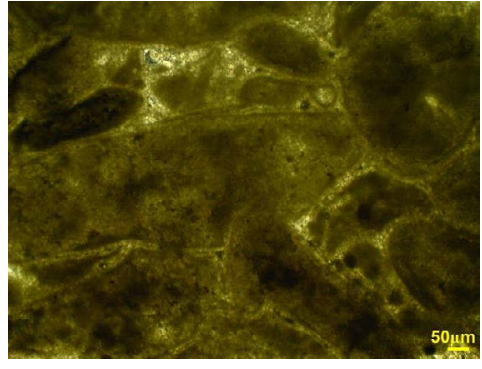

Figure 24. Facies E1 (Packstone with ramp- derived intraclasts), previously cemented micritic intraclasts, resulted by storm wave erosion found in mid-ramp (XPL).

\subsubsection{Facies E2 (Argillaceous Mudstone/Shale)}

The Carbonate allochems are absent. The Dark brown micrite includes clay minerals which is approved by sonic

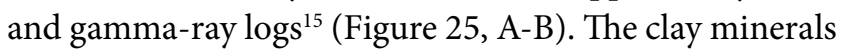
are common in various settings especially in marine environments but with attention to the position of this facies it is attributed to the mid-ramp settings. This facies contains "Condensed section" which is recognized by abundant clay minerals and sudden increase in gammaray response ${ }^{15,16}$ t

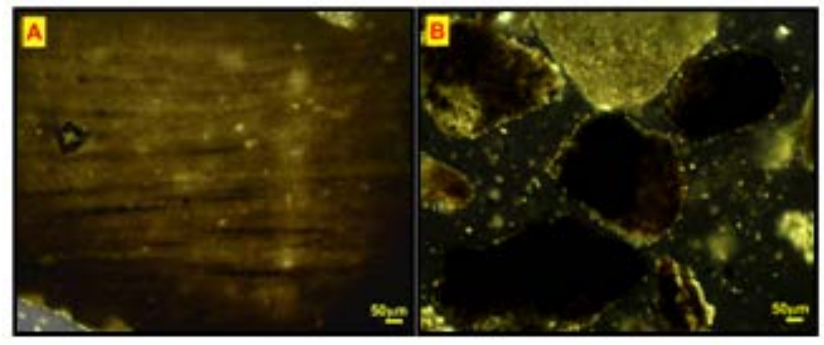

Figure 25. Facies E2 (Argillaceous mudstone/ shale) A) Argillaceous mudstone with thin lamination of clay minerals, B) Argillaceous mudstone associated with dark brown shale (XPL).

\section{Depositional Model of Dalan Formation}

Facies association classification integrated with sedimentological interpretations used to develop a depositional model for Dalan Formation in the study area (Figure 26). Shoreline high energy grainstones, benthic foraminifera accompanied by green algae and alsolack of breccias and calciturbidites denote a homoclinal ramp 
setting. Skeletal grains, ooids followed by peloids and intraclasts are common in carbonate ramps but other grains such as cortoids, oncoids, pisoids and aggregates are rare (Figure 27). To the northeast D1 and D2 facies appears which denote more distal ramp settings. The reservoir facies are common in inner shelf area with restricted circulation. The palaeolatitudes for the Khuff platform were about $20-25^{\circ} \mathrm{S}$ for the late Permian 47,48 , This places the platform in an arid and semi-tropical climate belt. This is consistent with the sedimentological and stratigraphic evidence from the study area which suggest more depositional evaporites and hypersaline lagoons in the Permian. The Dalan Formation is developed on the margin of the Neo-Tethys passive margin.

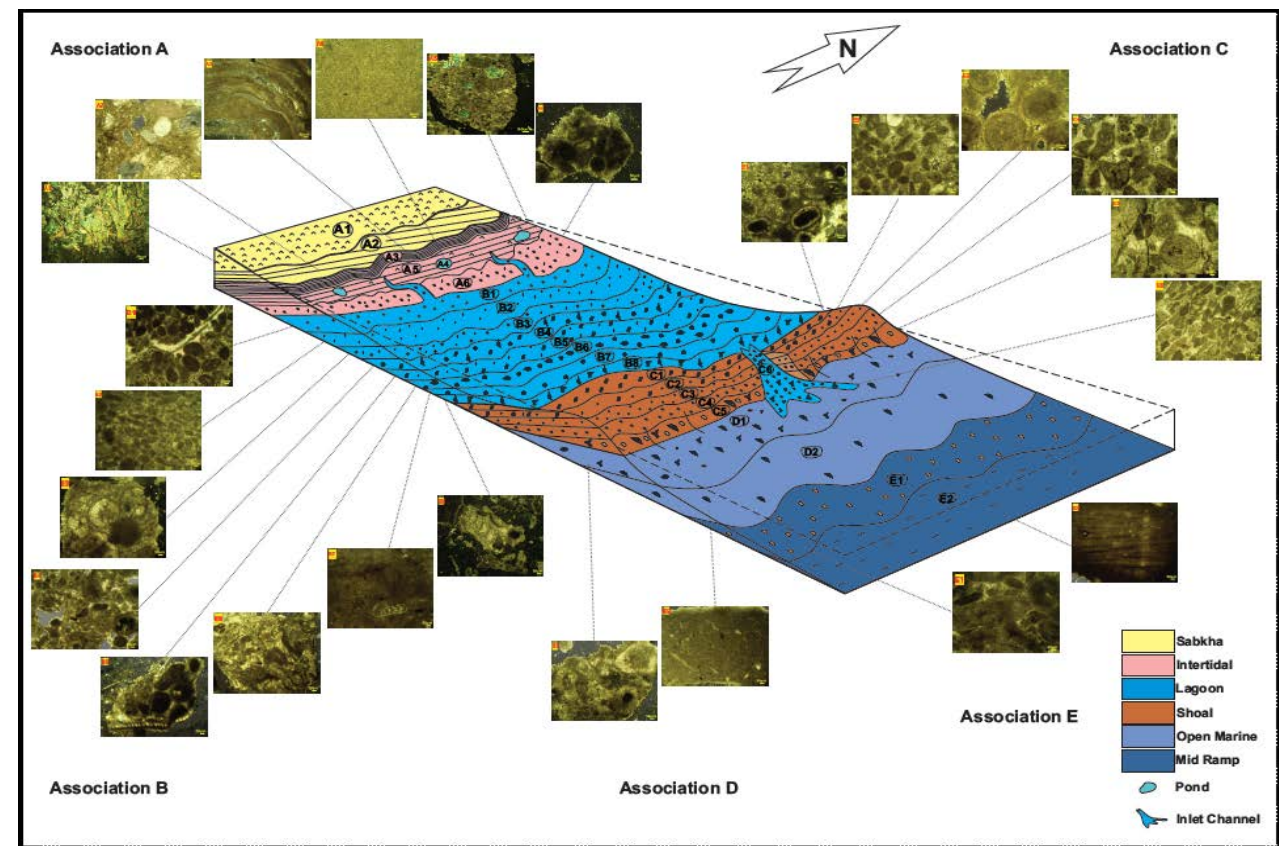

Figure 26. Conceptual depositional model of Dalan Formation in South Pars gas field (Well SP-A, subsurface section).

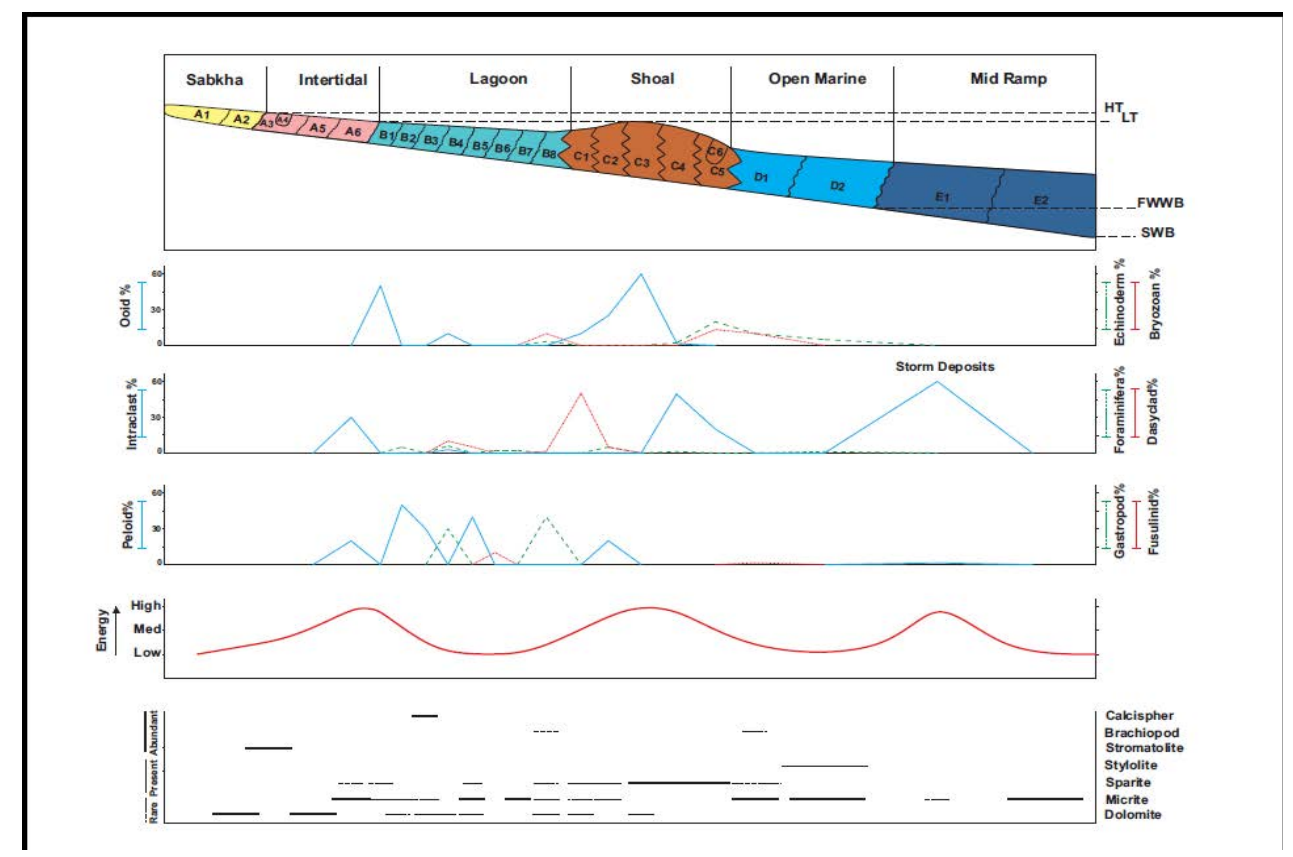

Figure 27. Depositional model of the Dalan Formation. The dominant grain types are ooids, peloids and intraclasts followed by skeletal grains which are indicative of carbonate ramps. 


\section{Sequence stratigraphy of Dalan Formation}

The stacking pattern and depositional environments employed to interpret sedimentary cycles. According to the floral and faunal events as well as sedimentary stacking pattern, seven major third- order depositional sequence were identified in the study area. The major transgression and highstand system track of Absaroka second-order cycle is located around the Lower and Upper Dalan respectively ${ }^{1}(\mathrm{AP} 6,270.6 \mathrm{Ma})$. The Dalan Formation comprises three reservoir units including K5 (Lower Dalan), K4 and K3 (Upper Dalan).

\subsection{Cycle 1 (LDS-1)}

The lower boundary of first depositional sequence with Faraghan Formation is Subaerial Unconformity (SU) but its upper boundary with LDS-2 is Correlative Conformity (CC). The transgressive system tract (TST) of this sequence includes lagoonal, shoal, open- marine and mid ramp facies in retrogradation stacking pattern. The maximum flooding surface (MFS) of LDS-1 is identified by mid-ramp shaly and argillaceous deposits including "condensed zone" (Picked by sudden increase in gammaray response) and corresponds to the P20 MFS off, Wor 1 off and sea-level rising off The highstand system tract (HST) of LDS-1 is consisting of open-marine, Shoal oolitic grainstoneto protected lagoonal and intertidal facies and is terminated by sabkha evaporitic facies and

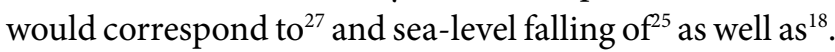
The lower boundary is correlated to the Global Stratotype Section and Point (GSSP, CC 268Ma) off and sea-level falling off as well as ${ }^{18}$ (Figure 28).

\subsection{Cycle 2 (LDS-2)}

This sequence encompasses the upper part of $\mathrm{K} 5$ reservoir. The MFS of this unit is marked by lagoonal fusulinid wackestone and would correspond to the Cap 1 of ${ }^{\circ}$ and sea-level rising off Nar Member and is identified by intertidal stromatolite boundstone that is capped by supratidal evaporitic facies. The upper boundary of this cycle is Correlative Conformity would correspond tosea-level falling off (Figure 28).

\subsection{Cycle3 (Nar-S)}

The upper boundary of Nar sequence is Correlative
Conformity and would correspond to sea-level falling off and GSSP (CC260.4 Ma) oft. The MFS of this unit is marked by lagoonal facies and would correspond to the Cap 2 offt. The abundant evaporitic facies denotes Middle Permian sea-level falling and global warming (Figure 29).

\subsection{Cycle 4 (UDS-1)}

This sequence contains lower part of K4 reservoir. The both lower and upper boundaries are Correlative Conformity. The transgressive system tract with retrogradation stacking pattern comprises a succession of shoal and open marine facies. The MFS of this unit is marked by mid-ramp facies. Due to global glaciations and melting events through the Late Permian period, the Upper Dalan Member includes abundant $4^{\text {th }}$ - order depositional cycles (Figure 30).

\subsection{Cycle 5 (UDS-2)}

This sequence includes the upper part of K4 unit. Its lower and upper boundaries are Correlative Conformity. The MFS is designated by open marine facies and coincides to the Wul offo, the P30 MFS off and sea-level rising of (Figure 30). Highstand system tract contains thick bioclastic/oolitic grainstones as a result of sea- level rising and thermal subsidence during glaciation and melting events

\subsection{Cycle 6 (UDS-3)}

The UDS-3 comprises lower part of K3 unit. Its upper boundary is Correlative Conformity. The TST with retrogradation stacking pattern contains lagoonalfacies. MFS of this unit is designated by B7 facies (Mudstone with lagoonal foraminifera) and coincides to Wu2 off and P40 (253 Ma) MFS offe. The HST with aggradation stacking pattern is covered by A4 facies (Intertidal pond) (Figure 30).

\subsection{Cycle 7 (UDS-4)}

The MFS is marked byB4 facies (Bioclast Wackestone/ Packstone) and would coincide to Chan 2 of . The Late Permian glaciation and melting events has created the small scale cycles ${ }^{28,48}$. The upper boundary is Correlative Conformity (No evidence of subaerial exposure) and corresponds to Tr10 oft, GSSP off and sea-level falling off (Figure 30). 


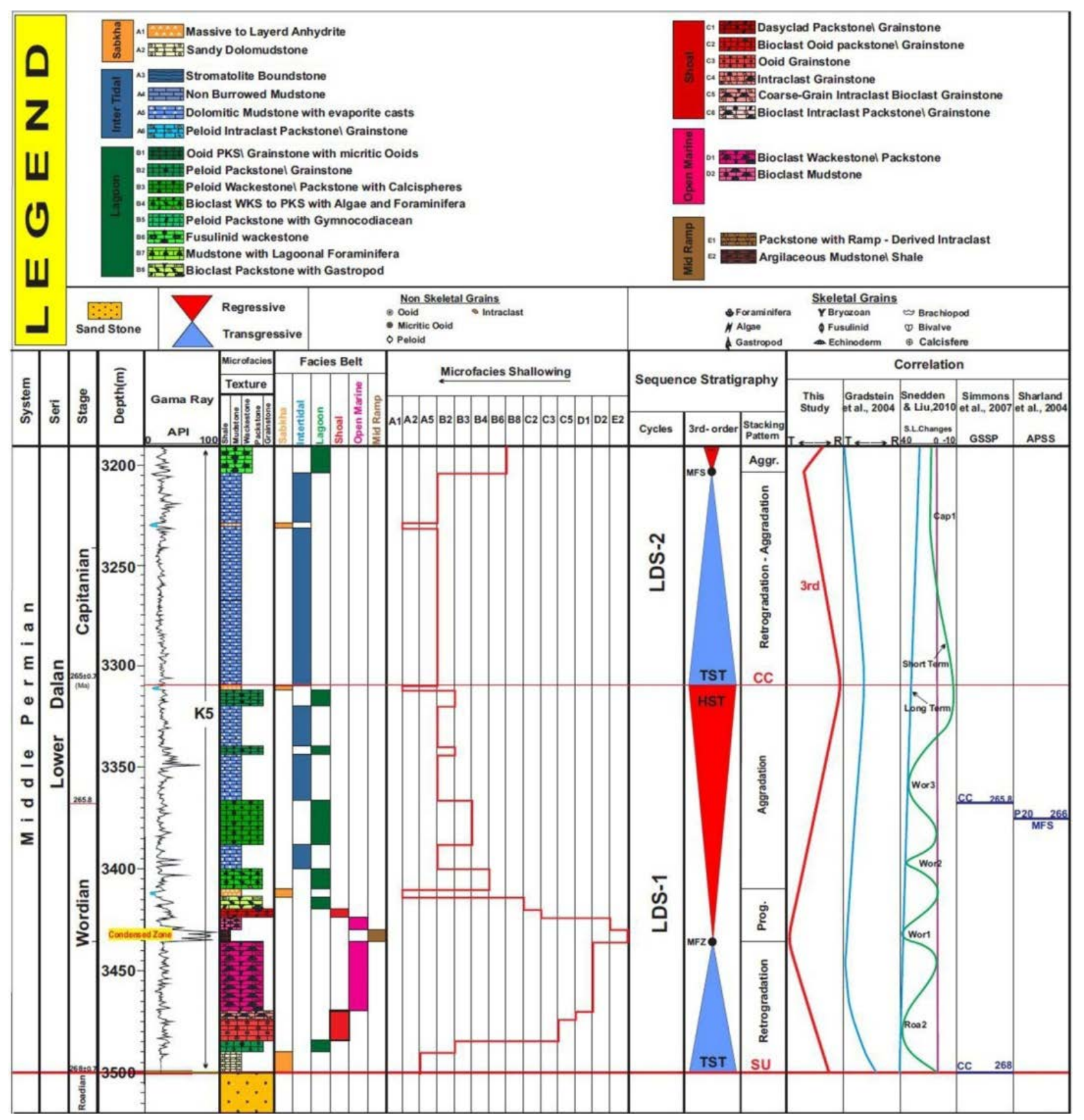

Figure 28. Lower Dalan Member transgressive- regressive cycles and their correlations with last calibrated sea-level Changes and Global Stratotype Section and Points (GSSP). 


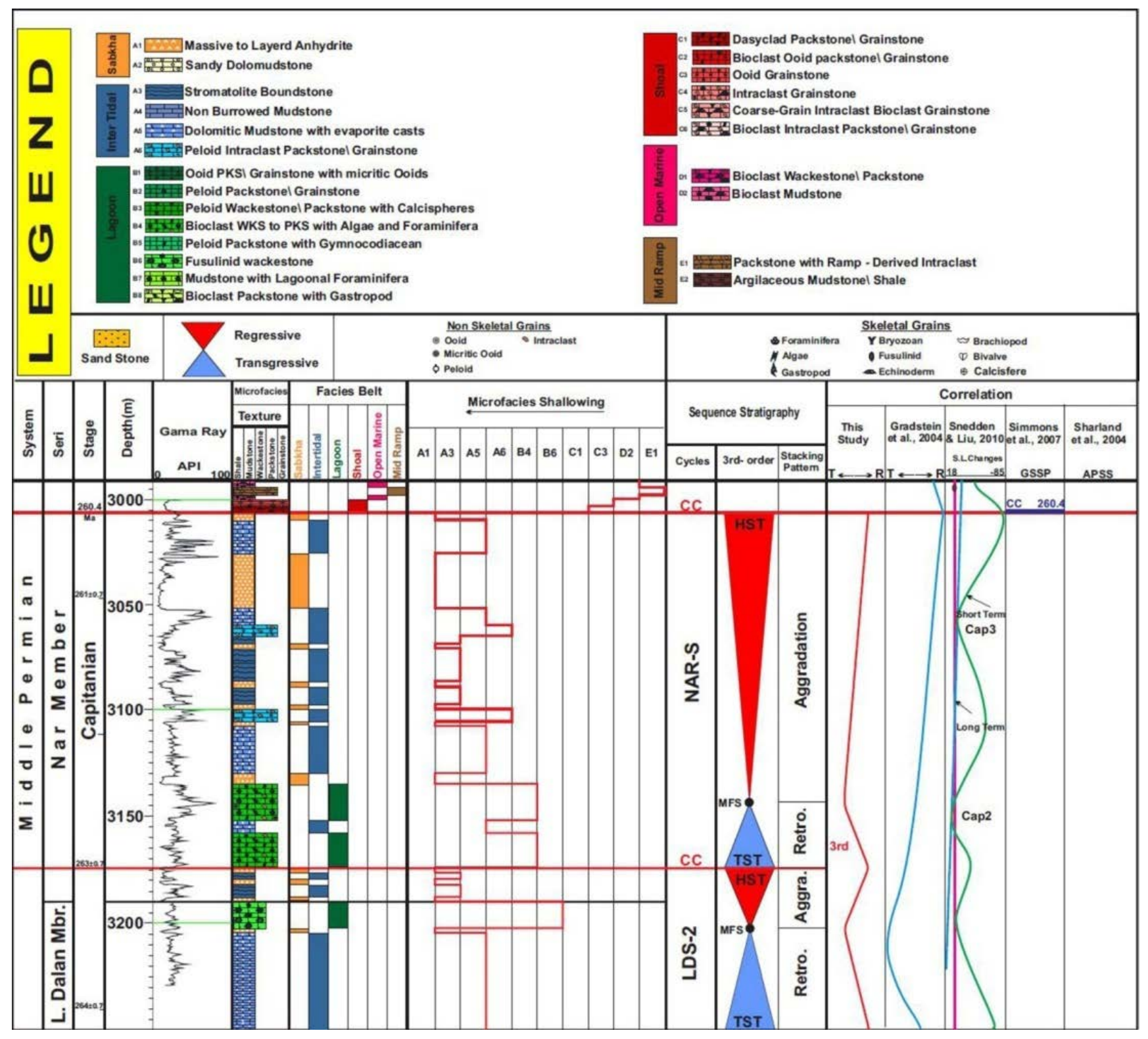

Figure 29. Nar member transgressive- regressive cycles and their correlations with last calibrated sealevel changes and Global Stratotype Section and Points (GSSP). 


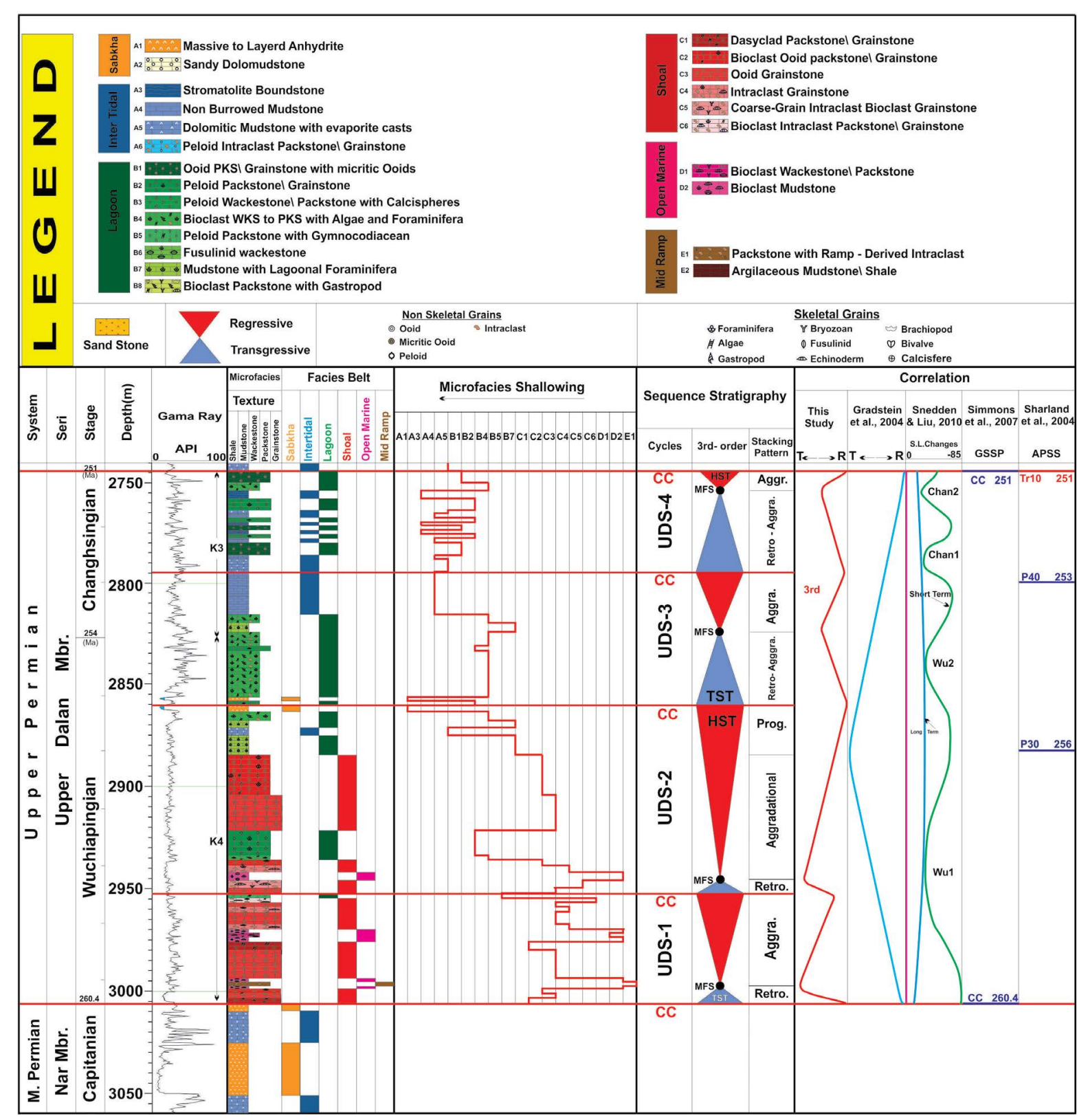

Figure 30. Lower Dalan Member transgressive- regressive cycles and their correlations with last calibrated sea-level Changes and Global Stratotype Section and Points (GSSP).

\section{Conclusion}

Five facies associations (Tidal Flat, Lagoon, Shoal, OpenMarine and Mid-Ramp) comprising twenty-four major facies were designated in the study subsurface section. Tidal Flat facies denoting global warming and sea-level fall are abundant in Nar Member as well as Upper Lower Dalan. The K3 reservoir (Upper Dalan Member) with good moldic and intergranular porosity has formed in restricted lagoons. The $\mathrm{K} 4$ unit consisting shoal grainstone has a good reservoir potential due to mimic dolomitization and well developed intergranular and moldic porosity. The open-marine faciesare common in lower Dalan Member. The E2 facies (Mid-Ramp)is characterized by "Condensed Zone"(Sudden increase in Gamma- Ray response) whereas the E1 facies (Storm deposits) comprises the MFS of Cycle 4. Shoreline high energy grainstones, benthic foraminifera accompanied by green algae and also lack of breccias and calciturbidites denote a homoclinal ramp setting. Skeletal grains, ooids 
followed by peloids and intraclasts are common in carbonate ramps. The Dalan Formation is developed on the margin of the Neo-Tethys passive margin. Seven major third- order depositional sequence were identified in the South Pars well SP-A. Owning to the major transgression of the Absaroka cycle, open- marine facies are common in the Lower Dalan Member.

\section{Acknowledgement}

The authors would like to thank NIOC Exploration for permission to publish this study. The authors would also like to express thanks to the people whom had valuable contribution to various aspects of this study.

\section{References}

1. Insalaco E, Virgone A, Courme B, Gaillot J, Kamali M, Moallemi A, Lotfpour M, Monibi S. Upper Dalan member and Kangan formation between the Zagros Mountains and offshore Fars, Iran: Depositional system, biostratigraphy and Stratigraphic architecture. GeoArabia. 2006; 11(2):746.

2. Fotovat M, Hosseini GH, Rahimpour-Bonab H. Sedimentary environment of upper Dalan Member in Qatar-Fars Arch and its eastern margin: South Pars and Salman fields (In Persian). Stratigraphy and Sedimentology Researches. 2012; 42(1):115-36.

3. Ghazban F. Petroleum geology of the Persian Gulf. Tehran University and National Iranian Oil Company: Tehran; 2007.

4. Edgell HS. The Permian system as an oil and gas reservoir in Iran, Iraq and Arabia. Proceedings of Second Iranian Geological Symposium; 1977. p. 161-201.

5. Perotti CR, Carruba S, Bertozzi G, Felter L, Rahimi M. The Qatar-South Fars Arch development (Arabian platform, Persian Gulf): Insights from seismic interpretation and analogue modelling. In: New frontiers in tectonic research- at the midst of plate convergence. Schattner U, editor, In Tech Publ.: Croati; 2011. p. 325-52. Crossref

6. Dunham RJ. Classification of carbonate rocks according to depositional texture. In: A Symposium on Classification of Carbonate rocks. WE Ham, editor, a symposium. AAPG Mem: Texas. 1962; 1:108-71.

7. Flügel E. Microfacies of carbonate rocks, analysis, interpretation and application. 2nd edn. Springer- Verlag: New York; 2010.

8. Carozzi AV. Carbonate rocks depositional model. Prentice Hall: New Jersey; 1989. PMCid:PMC267666

9. Davis RA, Dalrymple RW. Principle of tidal sedimentology. (eds.), Springer: Dordrecht Heidelberg London New York; 2012.

10. Warren JK. Evaporites: Sediments, resources and hydrocar- bons. Springer-Verlag: Berlin Heidelberg New York; 2006. Crossref

11. Lasemi Y. Facies analysis, depositional environments and sequence stratigraphy of the upper pre-Cambrian and $\mathrm{Pa}-$ leozoic rocks of Iran (in Persian). Geological Survey of Iran: Tehran, 2001.

12. Lasemi Y, Jahani D, Amin-Rasouli H, Lasemi Z. Ancient Carbonate Tidalites. In: Principle of Tidal Sedimentology. Davis RA, Dalrymple RW, editors, Springer: Netherlands; 2011. p. 567-607.

13. Mahboubeh A, Kohansal Ghadimvand N, Kangazian A, Hejazi SH. Sedimentary environment and sequence stratigraphy of the lower cretaceous deposits in the bideshk area, at North of Esfahan, Iran. Indian Journal of Science and Technology. 2015; 8(17). Crossref

14. Mahboubeh A, Ghadimvand NK, Kangazian A, Hejazi SH. Facies analysis, sedimentary environment and sequence stratigraphy of the lower cretaceous deposits in the Kalahroud area, at North of Esfahan, Iran. Indian Journal of Science and Technology. 2015. Crossref

15. Catuneanu O. Principles of sequence stratigraphy. 1st edn. Elsevier: Italy; 2006. Crossref1 Crossref2

16. Catuneanu O, Abrea V, Bhuttacharya JP, Blum MD, Dalrymple RW, Eriksson PG, Fielding CR, Fisher WL, Galloway WE, Gibling MR, Giles KA, Holbrook JM, Jordan R, Kendall CGSTC, Macurda B, Martinsen OJ, Miall AD, Neal JE, Nummedal D, Pomar L, Posamentier HW, Pratt BR, Sarg JF, Shanley KW, Steel RJ, Strasser A, Tucker ME, Winker C. Towards the standardization of sequence stratigraphy. Earth-Science Reviews. 2009; 92:1-33. Crossref

17. Catuneanu O, Galloway WE, Kendall CGSTC, Miall AD, Posamentier HW, Strasser A, Tucker ME. Sequence stratigraphy: Methodology and nomenclature. Newsletters on Stratigraphy. 2011; 44(3):173-45. Crossref

18. Snedden JW, Liu C. A compilation of Phanerozoic sea-level change, coastal onlaps and recommended sequence designation [Internet]. [cited 2010 Aug 20].Available from: Crossref

19. Haq BU, Shutter SR. A chronology of Paleozoic sea-level changes. Science. 2008; 322(5898):64-8. Crossref

20. Haq BU, Al-Qahtani AM. Phanerozoic cycles change on Arabian platform. GeoArabia. 2005; 10(2):127-60.

21. Bendias D, Koehrer B, Obermaier M, Aigner T. Mid-Permian Khuff sequence KS6: Paleo relief- influenced facies and sequences patterns in the Lower Khuff time-equivalent strata, Oman Mountains, Sultanate of Oman. GeoArabia. 2013; 18(3):135-78.

22. Koehrer B, Aigner T, Forke H, Pöppelreiter M. Middle to Upper Khuff (Sequences KS1 to KS4) outcrop equivalents in the Oman Mountains: Grainstone architecture on a sub regional scale. GeoArabia. 2012; 17(4):59-104.

23. Koehrer B, Zeller M, Aigner T, Pöppelreiter M, Milory P, Forke H, Al-Kindi S. Facies and stratigraphic framework of a Khuff outcrop equivalent: Saiq and Mahil formations, Al Jabal al-Akhdar, Sultanate of Oman. GeoArabia. 2010; 15(2):91-156. 
24. Shen SZ, Schnider JW, Angiolini L, Henderson CM. The international Permian time scale: March 2013 updated. In: The Carboniferous- Permian Transition. Lucas SG et al., editor, Museum of Natural History and Science: New Mexico. 2013; Bulletin 60: 411-16.

25. Gradstein FM, Ogg JC, Smith AG. A geological time scale. Cambridge University Press: New York; 2004.

26. Sharland PR, Casey DM, Davies RB, Simmons MD, Sutcliffe OE. Arabian plate sequence stratigraphy. GeoArabia. 2004; 9(1):199-214.

27. Simmons MD, Sharland PR, Casey DM, Davies RB, Sutcliffe OE. Arabian plate sequence stratigraphy: Potential implications for global chronostratigraphy. GeoArabia. 2007; 12(4):101-30.

28. Lotfpour M, Adabi MH, Sadeghi A, Moallemi SA. Sedimentary environment and sequence stratigraphy of Dalan Formation in Zagros area (In Persian). Journal University Science Tehran. 2005; 31(1):199-28.

29. Aleali M, Rahimpour-Bonab H, Moussavi-Harami R, Jahani D. Environmental and sequence stratigraphic implications of anhydrite textures: A case study from Lower Triassic of Central Persian Gulf. Journal of Asian Earth Science. 2013; 75:110-25. Crossref

30. Teymourzadeh H, Vaziri SH, Jahani D, Ghadimvand NK, Yahyaei A. Exploration characteristics and Lithostratigraphy of the Kangan and upper Dalan formations in Lavan gas field, Northen Persian Gulf. Academic Research Part A. 2014; 6(5):311-20.

31. Jahani D, Ghadimvand NK, Mohammad -Jafari P. Anhydrite fabrics in kangan Formation (Lower Triassic) in Fars and Zagros sub-basins (In Persian). Journal of Salt. 2012; $1(2): 13-18$.

32. Zamannejad A, Jahani D, Lotfpour M, Movahed B. Mixed evaporite/ carbonate characteristics of the Triassic Kangan Formation, offshore area, Persian Gulf. Revista Mexicana de Ciencias Geológicas. 2013; 30(3):540-51.

33. Tucker ME, Wright VP. Carbonate sedimentology. Blackwell Publishing Company: UK; 1990.

34. Alsharhan AS, Kendall CGSTC. Holocene coastal carbonate and evaporites of the southern Arabian Gulf and their ancient analogues. Earth Science Reviews. 2002; 61(34):191-43. Crossref

35. Gundogan I, Mehmet O, Depçi T. Sedimentology, petrography, and diagenesis of Eocene-Oligocene evaporites: The Tuzhisar Formation, SW Sivas Basin, Turkey. Journal of Asian Earth Science. 2005; 25(5):791-803. Crossref

36. Strasser A. Black-pebble occurrence and genesis in Holocene carbonate sediments (Florida Keys, Bahamas and Tunisia). Journal of Sedimentary Petrology. 1984; 54(4):1097109. Crossref
37. Steinhoff I, Strohmenger C. Zechstein 2 carbonate platform subfacies and grain-type distribution (Upper Permian, Northwest Germany). Facies. 1996; 35(1):105-32. Crossref

38. Khalifa MA. Lithofacies, diagenesis and cyclicity of the 'Lower Member' of the Khuff Formation (Late Permian), Al Qasim Province, Saudi Arabia. Journal of Asian Earth Sciences. 2005; 25(5):719-34. Crossref

39. Berkyová S, Munnecke A. Calcispheres as a source of lime mud and peloids - Evidence from the early middle Devonian of the Prague Basin, the Czeck republic. Bulletin of Geosciences. 2010; 85(4):585-602. Crossref

40. Madi A, Savard MM, Bourque PA, Chi G. Hydrocarbon potential of the Mississippian carbonate Platform, Bechar Basin. Algerian Sahara. 2000; 84(2):266-87.

41. Sadeghi M, Rashidi K, Shabanian R. Introducing the calcareous algae of Permian Dasyclads and Gymnocodiacean family, Pir- Eshagh section, South Jolfa, a report of Tabasoporella sp. from Dasyclad family in Northwestern Iran (In Persian). Geosciences. 2015; 24(95):55-66.

42. Karimi H, Ghadimvand NK, Kangazian A. Sedimentary environment and sequence stratigraphy of the Kangan formation in Kish Gas Field (Kish Well A1 subsurface section). Indian Journal of Science and Technology. 2015; 8(7). Crossref

43. Bathurst RGC. Carbonate sediments and their diagenesis. 2nd enlarged edition - Developments in Sedimentology. Elsevier: Amesterdam; 1975.

44. Madi A, Bourque PA, Mamet BI. Depth-related ecological zonation of a Carboniferous carbonate ramp: Upper Viséan of Béchar Basin, Western Algeria. Facies. 1996; 35(1):5980. Crossref

45. Calvet F, Tucker ME. Outer ramp cycles in the upper Muschelkalk of the Catalan basin, Northeast Spain. Sedimentary Geology. 1988; 57(3-4):785-98. Crossref

46. Posamentier HW, Allen GP. Siliciclastic sequence stratigraphy: concepts and applications. SEPM Concepts in Sedimentology and Paleontology Series 7. Society for Sedimentary Geology: Tulsa; 2000.

47. Stampfli GM. Tethyan Oceans. In: Tectonics and Magmatism in Turkey and the Surrounding Area. Bozkurt E, Winchester Ja, Piper JDA, editors. Geological Society of London: Special Publication. 2000; 173:1-23.

48. Angiolini L, Balini M, Garzanti E, Nicora A, Tintori A, Crasquin S, Muttoni G. Permian climatic and paleogeographic changes in Northern Gondwana: The Khuff Formation of Interior Oman. Palaeogeography, Palaeoclimatology, Palaeoecology. 2003; 191(3-4):269-300. Crossref 